\title{
Sedimentary Framework of the Western Gulf of Maine and the Southeastern Massachusetts Offshore Area
}

$\begin{array}{llllll}\text { WSEOLOGICAL SURVEY PROFESIONAL PAPER } & 757\end{array}$
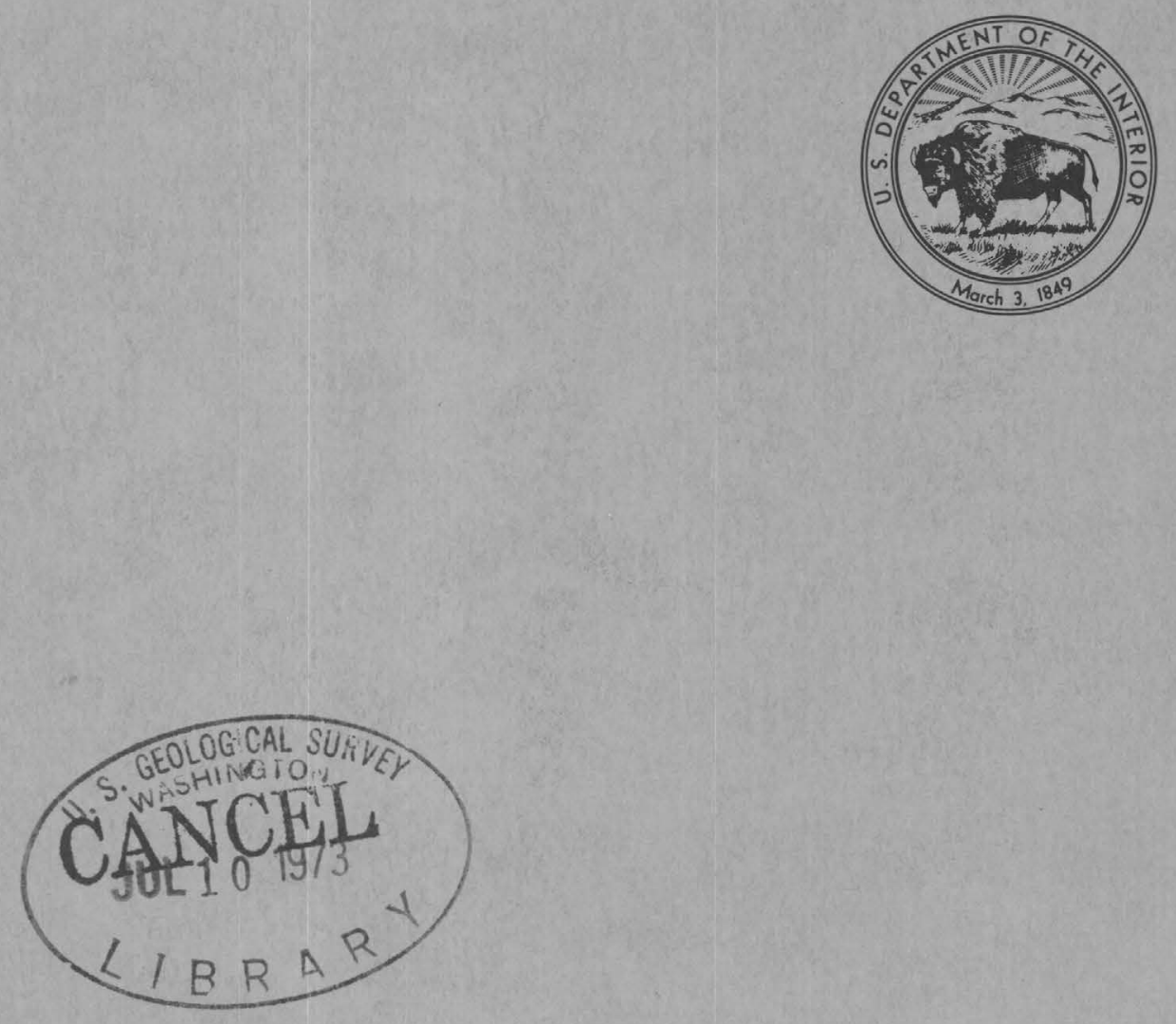



\section{Sedimentary Framework of the Western Gulf of Maine and the Southeastern Massachusetts Offshore Area}

By R. N. OLDALE, ELAZAR UGHUPI, and K. E. PRADA

GEOLOGICAL SURVEY PROFESSIONAL PAPER 757

Four sedimentary units ranging in age from

Cretaceous to Holocene have been inferred

from a seismic survey, and a preglacial

drainage system has been delineated

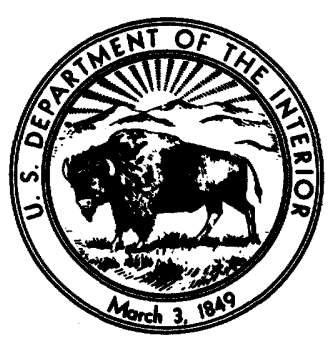


UNITED STATES DEPARTMENT OF THE INTERIOR

ROGERS C. B. MORTON, Secretary

GEOLOGICAL SURVEY

V. E. McKelvey, Director

Library of Congress catalog-card No. 72-600378

For sale by the Superintendent of Documents, U.S. Government Printing Office, Washington, D.C. 20402 Price: Paper Cover - \$1.75, domestic postpaid; \$1.50, GPO Bookstore. Stock No. 2401-00304 


\section{CONTENTS}

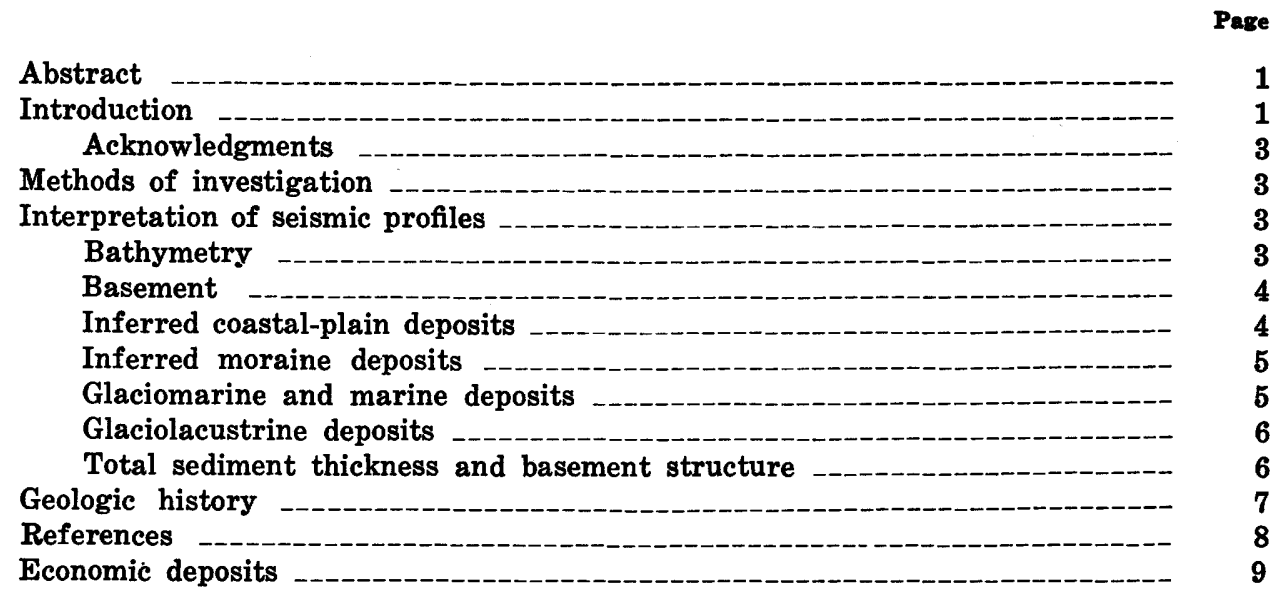

\section{ILLUSTRATIONS}

Plate 1. Generalized surficial geologic map and interpretive geologic sections of seismic profiles, western Gulf of Maine and southeastern Massachusetts offshore area 2. Reconnaissance isopach maps of bottom sediments and structure contour map of basement surface of the western Gulf of Maine and southeastern Massachusetts offshore area In pocket

Figure 1. Map showing bathymetry of the continental margin off northeastern United States and Nova Scotia 



\title{
SEDIMENTARY FRAMEWORK OF THE WESTERN GULF OF MAINE AND THE SOUTHEASTERN MASSACHUSETTS OFFSHORE AREA ${ }^{1}$
}

\author{
By R. N. Oldale, Elazar Uchupi, ${ }^{2}$ and K. E. Prada ${ }^{2}$
}

\begin{abstract}
The sedimentary framework of the western Gulf of Maine and the southeastern Massachusetts offshore area has been interpreted from data obtained with a seismic profiler, supplemented by information from geology on land and from samples offshore. A geologic map, three generalized isopach maps, and a generalized contour map of the basement surface provide significant information relative to the framework. Four sedimentary units have been distinguished on the basis of seismic data and are inferred to be: (1) coastal-plain sediments of Late Cretaceous to early Pleistocene age, (2) moraine deposits of Pleistocene age, (3) glaciomarine and marine deposits of Pleistocene and Holocene age, and (4) glaciolacustrine deposits of late Pleistocene age. The distribution of the inferred coastal-plain deposits delineates drainage systems whose streams are believed to have carved the following features out of the coastal-plain and the shelf strata: the Gulf of Maine, the cuesta beneath Georges Bank, and the islands off southern New England. This erosion is believed to have taken place during late Tertiary or early Pleistocene time. The inferred moraine deposits overlie basement rocks or the unconformity on the coastal-plain deposits; they define stages in the retreat of the last glacier in coastal New England. The acoustic unit assigned to the glaciomarine and marine deposits is believed to represent in part glacial rock flour carried into the marine environment by melt-water streams and in part silt and clay winnowed from the banks and ledges during the postglacial rise in sea level. The inferred glaciolacustrine deposits are thought to have been deposited in Cape Cod Bay during the retreat of the last ice in that area.
\end{abstract}

\section{INTRODUCTION}

Continental shelves of northern latitudes are topographically very irregular and are characterized by lowlands along the coast, U-shaped troughs extending from shore to the shelf's edge, and a chain of banks along the outer edge of the shelf (Holtedahl, 1958). This type of shelf occurs off New England

\footnotetext{
1 Contribution 2659 of the Woods Hole Oceanographic Institution, based on work done under a program conducted jointly by the U.S. Geological Survey and the Woods Hole Oceanographic Institution and financed by the U.S. Geological Survey.

- Woods Hole Oceanographic Institution, Woods Hole, Mass.
}

(fig. 1) and consists of the Gulf of Maine, a broad 90,700-km² lowland, and Georges Bank, which separates the gulf from the open ocean. Northeast and Great South Channels provide passageways from the Gulf of Maine to the Atlantic Ocean. Cape Cod Bay, Nantucket Sound, and Buzzards Bay make up smaller lowlands.

The floor of the Gulf of Maine is extremely irregular and is marked by deep basins, low swells, ridges, and flat-topped banks and ledges (Uchupi, 1968). In an early study, Johnson (1925, p. 264 296) suggested that the Gulf of Maine was carved out of continental-shelf strata by stream erosion. He further stated that the basins within the gulf mark positions of former stream valleys and that Northeast and Great South Channels were the water gaps of the two major streams of the drainage systems. The topographic highs within the gulf were interpreted by him as subordinate cuestas within the lowland. He also believed that Georges Bank was a cuesta cut in coastal-plain strata.

The wide occurrence of glacial deposits in the Gulf of Maine and the observation that the type of topography found off New England appears to be restricted to formerly glaciated coasts led Shepard, Trefethen, and Cohee (1934) to suggest that glacial erosion played a significant role in the formation of the gulf. On the basis of data obtained with a continuous seismic profiler, Uchupi (1966) and Oldale and Uchupi (1970) suggested that the Gulf of Maine probably was formed by a combination of preglacial fluvial erosion and Pleistocene glacial erosion. Using data from these profiles, Oldale and Uchupi (1970) were able to trace the preglacial fluvial systems that eroded the Gulf of Maine. Interpretation of seismic profiles also suggests that some of the basins are underlain by steeply dipping strata which acoustically resemble known Triassic sedimentary rocks in the Gulf of Maine and the Bay of Fundy (Tagg and 


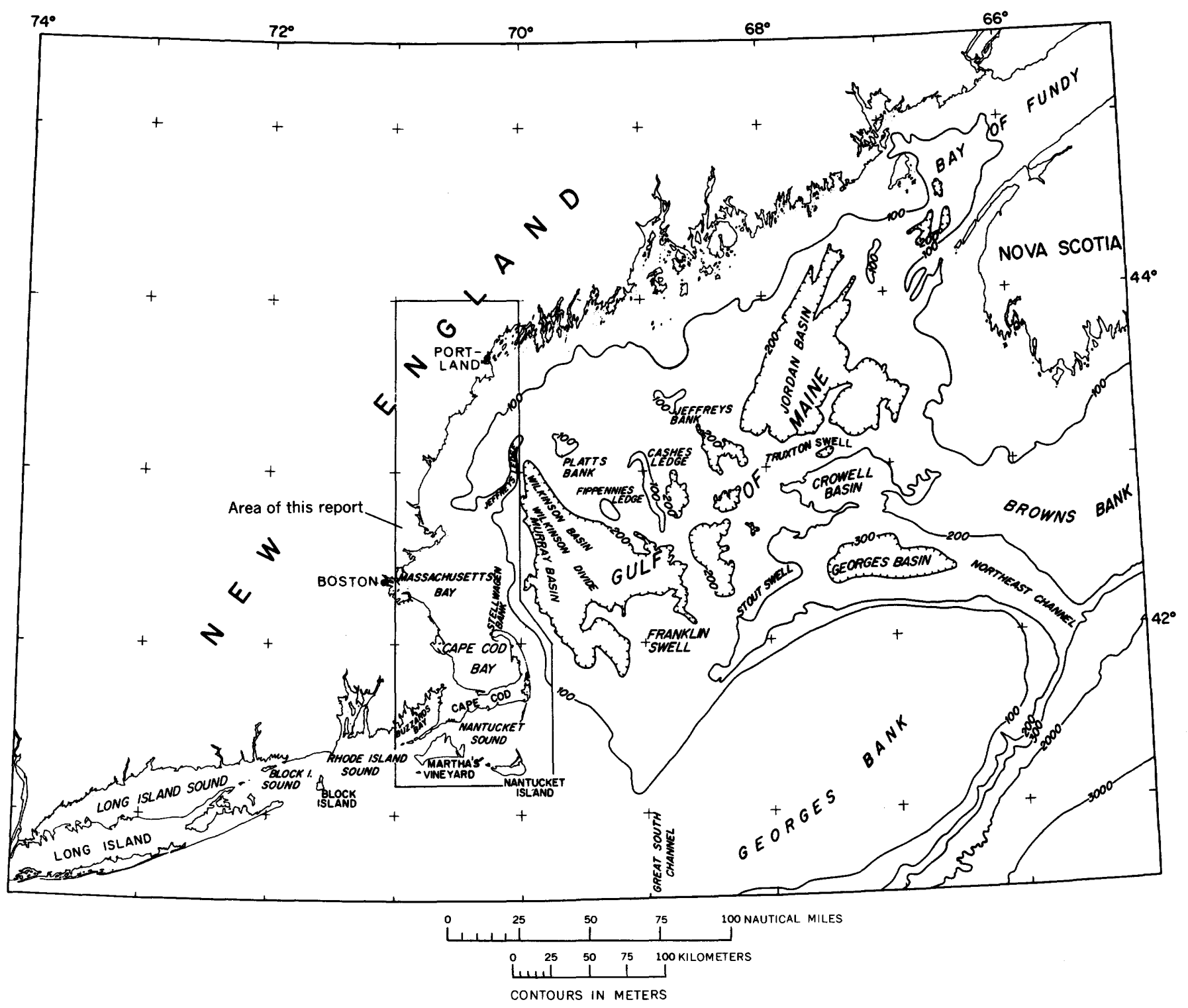

FIgURE 1.-Bathymetry of the continental margin off northeastern United States and Nova Scotia. Bathymetry from Uchupi (1965).

Uchupi, 1966; Uchupi, 1966). This interpretation led Oldale and Uchupi (1970) to speculate that the larger basins within the gulf represent Triassic fault basins modified to their present shape by fluvial and glacial erosion.

Most of these earlier studies were based on widely spaced seismic profiler records; consequently, the sedimentary framework of the offshore area could be reconstructed only in the broadest sense. With completion of a reconnaissance survey of the Atlantic continental margin of the United States, the U.S. Geological Survey, in cooperation with the Woods Hole Oceanographic Institution, began a more detailed geologic mapping program of the continental shelf. The first area chosen for more detailed study was the westernmost part of the Gulf of Maine (fig. 1). The large amount of seismic profiler data collected within this relatively small area has made possible the refinement of the reconstruction of the sedimentary framework of the central New England offshore area. Because the geologic formations that are segregated on the basis of their acoustical-reflection properties are mostly inaccessible to direct observation, the geologic interpretation of seismic profiles relies heavily on inference. Most of the unit identifications in this report, therefore, are referred to as "inferred." Seismic surveys are, however, the most expedient 
means of reconnoitering a marine area for structural and stratigraphic information. They provide a basis for planning and carrying out more specific geologic investigations whose results may prove or disprove the inferences that were made from the seismic data.

\section{ACKNOWLEDGMENTS}

The writers wish to thank the officers and crew of the R/V Gosnold and R/V Lulu for their cooperation during the survey. Ship time aboard R/V Lulu was provided by the U.S. Office of Naval Research (contract NONR 34-84). E. P. Curley of E.P.C. Laboratories, Inc., provided a recorder of his design used during the R/V Lulu cruise. C. L. Winget, G. A. Meier, and B. B. Walden of the Woods Hole Oceanographic Institution kept the seismic system in operation during the $\mathrm{R} / \mathrm{V}$ Lulu cruise. Thanks are also extended to W. O. Rainnie, head of the Deep Submergence and Engineering Section of the Ocean Engineering Department at Woods Hole Oceanographic Institution for his help in preparing $R / V$ Lulu for the cruise. Zvi Ben-Avraham of Woods Hole Oceanographic Institution-Massachusetts Institute of Technology, M. F. Kane of the U.S. Geological Survey, D. C. Jipa of the Geological Institute, Bucarest, Rumania, and R. D. Ballard, formerly of the U.S. Office of Naval Research in Boston and now at Woods Hole Oceanographic Institution, participated in shipboard surveys. For their suggestions during the preparation of this report we express our appreciation to J. D. Milliman, K. O. Emery, C. A. Kaye, Parke Snavely, and R. H. Meade.

\section{METHODS OF INVESTIGATION}

The main tool for defining the sedimentary framework of the western Gulf of Maine, Nantucket Sound, Vineyard Sound, and Buzzards Bay was a seismic profiler. The acoustic energy source was an air gun. A 5-cubic-inch chamber was used during the R/V Gosnold cruise, and a 10-cubic-inch chamber during the $\mathrm{R} / \mathrm{V}$ Lulu cruise. During both cruises, the gun was towed at a depth of $3 \mathrm{~m}$ (meters) and fired every 2 seconds. An operating pressure of 1,800 psi (pounds per square inch) was derived from a deck-mounted high-volume high-pressure dieseldriven compressor system. Signals from the bottom and subbottom reflectors were received by a $30-\mathrm{m}$, 200-element streamer array towed approximately $60 \mathrm{~m}$ astern of the vessel at a depth of $4 \mathrm{~m}$. A monolithic preamplifier with a 20-decibels (db) gain was inserted at the head of the array. The preamplifier output impedance was suitable for driving as much as $600 \mathrm{~m}$ of tow cable, while the $20 \mathrm{db}$ provided signals greater in amplitude than any tow noise generated by the tow cable. A broad-band monolithic amplifier with gain variable to $40 \mathrm{db}$ amplified the received signal. This signal was then fed to suitable line drivers, filtered passively, and recorded on a graphic recorder. During the $\mathrm{R} / \mathrm{V}$ Gosnold cruise, the signals were filtered in the band 150 to $250 \mathrm{~Hz}$ and recorded on a precision graphic recorder. During the $\mathrm{R} / \mathrm{V}$ Lulu cruise, filter settings were generally 100 to $300 \mathrm{~Hz}$, and a graphic recorder designed by E. P. Curley was used. Recorders were set at a 0.5 second scan. The air gun was triggered every fourth scan, and the first of the four scans was recorded. Navigation was by Loran A supplemented by radar and visual fixes. During the $\mathrm{R} / \mathrm{V}$ Gosnold cruise, fixes were taken every 60 minutes and every 20 minutes during the R/V Lulu cruise. Ship's speed during both cruises was $11 \mathrm{~km}$ per hour.

\section{INTERPRETATION OF SEISMIC PROFILES}

Seismic profiles (pl. 1) were interpreted visually by placing an acetate sheet over the records and tracing the individual reflectors with a grease pencil. These interpretations were then reduced visually to line drawings and at the same time corrected for variations in ship speed. Inferences as to the geologic nature of the acoustic units were made generally on the basis of known geologic history on land, from acoustic signatures of known geologic units, and, where possible, from rock samples offshore. Generalized isopach maps of the sedimentary units inferred from seismic data, a total sediment thickness map, and a structure contour map of the basement surface were compiled by assuming velocities of $1.5 \mathrm{~km}$ per sec for water, $1.5 \mathrm{~km}$ per sec for the inferred upper Pleistocene lacustrine and marine sediments and Holocene marine sediments, and $1.7 \mathrm{~km}$ per sec for the inferred glacial moraine and coastal-plain sediments. (See pl. 2.) Although velocity data for these units were not obtained during the present investigations, compressive velocities measured in the Gulf of Maine (Drake and others, 1954) and along the coast (Oldale, 1969) suggest that the assumed velocities are reasonable.

\section{BATHYMETRY}

The area of investigation is along the western margin of the Gulf of Maine and southeastern Massachusetts, enclosing within its boundaries that section of the sea floor from long $69^{\circ} 40.5^{\prime}$ to $71^{\circ} 00^{\prime}$ 
in the southern part and from long $70^{\circ} 00^{\prime}$ to $71^{\circ} 00^{\prime}$ in the northern part, and from lat $41^{\circ} 10^{\prime}$ to $43^{\circ} 50.2^{\prime}$. The most prominent topographic submarine features in this area are Jeffreys Ledge and Stellwagen Bank (pl. 1). Both topographic highs diverge from Cape Ann, and Stellwagen Bank extends almost to the northern tip of Cape Cod. Depths along their flat tops range from less than $40 \mathrm{~m}$ on Stellwagen Bank to less than $60 \mathrm{~m}$ along most of Jeffreys Ledge. Between the topographic highs on the seaward side is a wide delta-shaped platform that includes Tillies Basin and Tillies Bank. Tillies Basin has a complicated outline consisting of two narrow north-trending depressions on the east and a northwest-trending one on the west. The eastern depressions are separated by Tillies Bank. The slope along long $70^{\circ} \mathrm{W}$. that forms the eastern side of this delta-shaped platform is deeply entrenched by gullies (pl. 1).

The sea floor between Jeffreys Ledge and the coast is quite irregular and is marked by numerous highs and narrow depressions. South of lat $43^{\circ}$, the sea floor near the coast is much smoother, and most topographic irregularities are restricted to the area inside the $20-\mathrm{m}$ contour. The smoothest area north of Cape Cod occurs within Cape Cod Bay; only the 10-m-high Fishing Ledge disrupts the continuity of the sea floor. Topographic irregularities within Nantucket and Vineyard Sounds are due to shoals which are believed to be in part modified relict morainal ridges and sand ridges formed by longshore drift during the last rise in sea level (Smith, 1969). On the eastern side of Buzzards Bay and in the narrow tidal inlets in the Elizabeth Islands, much of the sea floor is irregular, but because the topographic relief of these irregularities is less than $20 \mathrm{~m}$, they are not shown on the contour configuration of the base of plates 1 and $2 A-D$. In other places, the bay's floor is somewhat smoother. With the exception of Nantucket and Vineyard Sounds, the irregularity of the sea floor appears to be controlled in large part by the amount of sediment cover over the basement. In the area along the western side of Buzzards Bay and west of Jeffreys Ledge, sediments are very thin or absent, and the sea-floor topography reflects the morphology of the basement. A somewhat thicker cover produced the more subdued topography on the sea floor west of Stellwagen Bank and in the area along the eastern side of Jeffreys Ledge and Stellwagen Bank. The relatively smooth topography of Cape Cod Bay, Jeffreys Ledge, and Stellwagen Bank is due to the great amount of sediment present in these areas.

\section{BASEMENT}

The strong reflector at the base of the seismic profiler sequence has been traced in many places to within short distances of the shore, where crystalline and sedimentary rocks of pre-Cretaceous age (basement) crop out. With but few exceptions, this reflector can be traced continuously throughout the area, and everywhere it is inferred to represent the upper surface of the basement.

Subbasement acoustic reflectors were observed east of Tillies Basin and Jeffreys Ledge (pl. 1, profiles 309 and 321). Their similarity to subbottom reflectors in areas of known Triassic sedimentary rocks in the eastern Gulf of Maine (Tagg and Uchupi, 1966 ; Uchupi, 1966) suggests that the basement in these areas is the same. This similarity appears to substantiate Oldale's and Uchupi's (1970) suggestion that the major basins in the Gulf of Maine are structural features formed during the Triassic. Another area where subbasement reflectors were observed is the east entrance to Nantucket Sound. These reflectors may also represent areas underlain by Triassic sedimentary rocks, but the proximity to Carboniferous sedimentary rocks in the Narragansett and Boston Basins suggests that these rocks may be Carboniferous. An attempt to trace the Carboniferous sedimentary rocks in the Boston Basin failed, however, because subbasement reflectors were absent, and the rocks could not be distinguished acoustically from the igneous and metamorphic rocks in the area. The seismic records show that the surface of the basement is generally more irregular where it forms the sea bottom or where it is overlain solely by glacial or postglacial deposits than where it is overlain by sediments inferred to be coastal-plain deposits. Thus, in general, the basement surface is more irregular north of Cape Ann, in Buzzards Bay, Cape Cod Bay, and parts of Vineyard Sound, where it was glaciated, than beneath Jeffreys Ledge, Stellwagen Bank, and Nantucket Sound, where it was protected from glacial erosion by coastal-plain deposits. The degree of roughness of the basement surface may also be due to differences in erodibility of the rock units that form the basement.

\section{INFERRED COASTALPLAIN DEPOSITS}

The basement is overlain in places by an acoustic unit characterized by well-defined flat continuous internal reflectors and an irregularly undulating uppermost acoustic surface that in places truncates the internal reflectors (pl. 1). The uppermost surface is inferred to be an unconformity underlain by 
coastal-plain sediments of Late Cretaceous to early Pleistocene age. The acoustic characteristics of this unit are similar to those on seismic records from coastal-plain deposits of Tertiary age (Schlee and Cheetham, 1967) which underlie Fippennies Ledge (Uchupi, 1966) and to those on seismic records from erosional remnants of Cretaceous deposits on the Scotian Shelf (King and others, 1970). Additional reasons for inferring that the acoustic unit represents coastal-plain deposits include: the fossiliferous boulders of Eocene age (Crosby, 1879), the silicified and carbonaceous wood of Tertiary age, and glauconite in the drift of Cape Cod (Oldale, 1968); the erosional remnants of Miocene and Eocene sediments in Marshfield and Scituate and on Nonomesset Island (Bowman, 1906; Emerson, 1917; Woodworth and Wigglesworth, 1934) ; and the coastal-plain deposits of Miocene and Late Cretaceous age beneath Martha's Vineyard and Georges Bank (Woodworth and Wigglesworth, 1934 ; Stetson, 1949 ; Gibson and others, 1968).

The acoustic unit inferred to be coastal plain may in part represent older glacial drift. If so, it is separated from the drift of the last ice sheet by an unconformity that represents an interval of erosion during an interglacial stage or substage. This interpretation seems unlikely, however, as interglacial times are generally characterized by deposition on the coastal plain and shelf during high sea-level stands. The deposits of Aftonian age on Martha's Vineyard (Kaye, 1964) and the presence of fossil shells in the drift of Farmdalian Age on outer Cape Cod (Oldale, 1968) indicate high stands of sea level during those interglacial times.

Seismic data indicate that the coastal-plain deposits (pl. 2A) form the core of the major bathymetric highs north of Cape Cod and underlie Nantucket Sound and the islands to the south. The isopach map (pl. 2A) delineates a drainage system that can be traced to the western edge of Murray Basin, the eastern and southern margins of Nantucket Sound, the mouth of Vineyard Sound, and the entrance of Buzzards Bay. The system draining from the vicinity of Cape Ann may represent seaward extensions of the rivers north of this cape. The narrow depressions forming Tillies Basin appear to be remnants of this drainage system, as do the gullies east of Stellwagen Bank. Other channels appear to have been formed from the drainage system out of Massachusetts Bay and Cape Cod Bay. Several of these channels extend across Stellwagen Bank to connect with the gullies east of this bank. The drainage system appears to have been little affected by subsequent glaciation of the region. These channels are probably seaward extensions of the buried ones on land that were described by Upson and Spencer (1964). The valleys represent streams that probably carved the lowlands forming the Gulf of Maine, Nantucket and Vineyard Sounds, Buzzards Bay, the cuesta beneath Georges Bank, and the islands south of Massachusetts.

\section{INFERRED MORAINE DEPOSITS}

A thick acoustically defined unit occurs in many places above the erosion surface of late Tertiary or early Pleistocene age beneath and seaward of Jeffreys Ledge and Stellwagen Bank and in the areas east and south of Cape Cod. It locally overlies the basement surface (pl. 1) nearer shore. The upper surface of this unit is characterized by a nonsystematic pattern of topographic highs and lows. Reflecting horizons within the unit are generally discontinuous and irregular in profile, and individual and grouped parabolic-shaped reflectors are common. The unit is generally thickest in channels cut in the deposits assigned to the coastal plain. This acoustic unit is inferred to be equivalent to the thick accumulations of glacial drift exposed above sea level on Cape Cod and the islands south of Cape Cod. Although the term "moraine" is most often associated with deposits composed mostly of till (Flint, 1947, p. 126), it is used here to identify deposits generally thought to have formed close to glacial ice, including fluvial ice-contact and outwash deposits, proglacial deltaic deposits, and basal and superglacial till. The discontinuous and irregular reflectors, irregular upper surface, and parabolic reflectors, believed to be boulders or gravel, are thought to represent sediments deposited in the chaotic depositional environments associated with nearby glacial ice. The unit probably represents deposits of more than one glaciation in a manner similar to the Pleistocene section on Martha's Vineyard, where deposits of all the major glacial stages are inferred to be present (Kaye, 1964).

\section{GLACIOMARINE AND MARINE DEPOSITS}

The uppermost seismic unit in the basins landward of Jeffreys Ledge and Stellwagen Bank, in topographic lows in the basement along the coast, and locally in lows in the inferred moraine and coastal-plain deposits offshore (pl. 1) is characterized by a relative acoustic transparency. As this characteristic best defines the unit, it is here called the transparent layer. The unit can be penetrated by high-frequency $(3.5-$ to $12.0-\mathrm{kHz})$ as well as 
low-frequency (100- to $300-\mathrm{Hz})$ subbottom profiling. Numerous internal reflectors can be seen in the transparent layer, and locally, reflectors defining cutand-fill and slump structures are present. In some places, continuous internal reflectors are absent, and the unit has a mottled appearance in the records. Generally, the unit has a flat upper surface.

The thickness of the unit varies greatly because it is controlled in large part by the surface configuration of the material below it. Maximum thickness found during the survey was $100 \mathrm{~m}$ in Tillies Basin. In many other places, thickness exceeds 30-40 m.

Sediments in the uppermost part of this transparent layer have been extensively sampled and are known to consist of silt and clay of Holocene age. In Boston Harbor, boreholes near 3.5-kHz subbottom profiles showed the upper part of the layer to be silt and clay of Holocene age and the lower part to be glaciomarine silt and clay of late Pleistocene age (R. H. Burroughs, oral commun., 1970). A similar correlation is inferred for the transparent layer offshore. The mottling shown in the records is inferred to represent local deposits of coarser grained material, perhaps sand and gravel, within the silt and clay. The silt and clay represented by the transparent layer thus have a complex origin. Initially, most of the material consisted of glacial rock flour carried to the sea by melt-water streams and deposited in the basins. Later, as the rising Holocene sea submerged the banks and ledges, silt and clay were winnowed from glacial drift by wave action and carried into the basins by currents. Finally, the upper part of the silt and clay deposit probably contains some material carried to the sea by modern streams.

No internal reflector within the transparent layer could clearly be inferred to be an unconformity between the glaciomarine and Holocene marine deposits. This fact suggests that in most places, offshore deposition has been continuous since late Pleistocene time.

Contact relationships between the upper Pleistocene to Holocene marine deposits and moraine deposits are complex. The moraine deposits represent in part subaerial facies of the glaciomarine deposits. Near the contacts between these units the sediments may grade from one to the other. Similarly, the marine deposits of Holocene age, although stratigraphically younger, grade laterally into reworked glacial drift on the topographic highs. Thus, in many places, a reflector representing the contact between these units was not present in the seismic records.

\section{GLACIOLACUSTRINE DEPOSITS}

The upper acoustic unit in Cape Cod Bay and slightly north of the bay rests on basement in most places and locally on the acoustic units inferred to be remnants of coastal-plain deposits or moraine deposits. A survey of Cape Cod Bay using a highresolution seismic profiler (Hoskins and Knott, 1961) showed the unit to be composed of two parts. The lower part has numerous horizontal internal reflectors and becomes thicker to the north. The upper part has fewer continuous internal reflectors and locally is characterized by internal parabolic reflectors. This upper part thickens toward the south. Hoskins and Knott (1961) inferred that the lower part represented coastal-plain deposits of Tertiary age. They believed that the upper part was glacial drift of Pleistocene age and that the parabolic reflectors represented boulders or gravel within the deposit. As no reflectors that might represent an unconformity were observed between the upper and lower part, we have inferred that the acoustic unit represents deposits wholly of Pleistocene age, perhaps glaciolacustrine sediments deposited in Cape Cod Bay during the retreat of the last ice.

\section{TOTAL SEDIMENT THICKNESS AND BASEMENT STRUCTURE}

Total sediment thickness and depth to basement, as determined from seismic data, are shown on plate $2 C$ and $D$. Much of the sea floor adjacent to the coast as far south as Plymouth consists of closely spaced topographically high basement outcrops separated by topographic lows containing sediment less than $20 \mathrm{~m}$ thick. Seaward of this coastal zone and south of Plymouth the sediments gradually thicken, and outcrops of the basement are absent. The sediments are thickest beneath Jeffreys Ledge, Stellwagen Bank, Cape Cod, Nantucket Sound, and the islands farther south. Within these areas the greatest thicknesses occur in narrow troughs. A well-developed drainage system is defined by both maps particularly south of Cape Ann. Many of these valleys appear to be offshore extensions of major streams of present drainage systems, that is, extensions of the Merrimack River and the streams that drain Boston Harbor. Other submarine valleys like the ones off Plymouth and in Nantucket and Vineyard Sounds may be offshore extensions of preglacial river valleys now buried by glacial drift on land. As many of the submarine valleys are wholly or in part filled with sediment inferred to be moraine, the drainage is thought to be preglacial. The streams carved the lowlands and cuestas out of the continental shelf 
strata. North of Cape Ann, the seismic lines are far apart, and only one major drainage system could be delineated.

\section{GEOLOGIC HISTORY}

On the basis of seismic data obtained during the present study and supplemented by information available on land, the geologic history of the western Gulf of Maine, Cape Cod, Nantucket and Vineyard. Sounds, Buzzards Bay, Nantucket, and Martha's Vineyard can be summarized as follows. Until Cretaceous time the history of the area may have been similar to that indicated by the onland geology. The sedimentary, tectonic, and erosional cycles that left their imprint on land should also have played a part in the formation of the basement now present offshore. During most of Paleozoic and early Mesozoic time, New England was an area of plutonic and volcanic activity. During the Carboniferous, narrow fault troughs that filled with continental deposits developed in some places. Boston Basin represents one such trough that extends offshore. A more extensive series of fault troughs that filled with continental sediments formed during the Triassic, and many of the larger basins in the Gulf of Maine are thought to be offshore equivalents of the Triassic basins on land.

Upper Cretaceous continental deposits on Martha's Vineyard (Woodworth and Wigglesworth, 1934) suggest that much of the area may have been above sea level during Late Cretaceous time. Meanwhile, marine deposition was taking place along the shelf's edge as attested by the presence of Upper Cretaceous marine sediments in the submarine canyons south of Georges Bank (Stetson, 1949). In early Tertiary time, the Gulf of Maine and the shelf to the west were submerged; the transgression of the sea reached its peak during the Miocene, as indicated by the Miocene glauconitic sediments along the coast south of Cape Ann (Bowman, 1906; Emerson, 1917). In late Tertiary or early Pleistocene time, sea level dropped, or the region was uplifted. Streams extended their courses across the shelf and carved a series of lowlands beneath Buzzards Bay, Vineyard and Nantucket Sounds, and the Gulf of Maine, and they carved cuestas beneath the Elizabeth Islands, Martha's Vineyard, Nantucket, Stellwagen Bank, Jeffreys Ledge, and Georges Bank. Erosional remnants were left beneath the smaller banks within the Gulf of Maine. Great South and Northeast Channels were the water gaps of much of this drainage system.
The glacial chronology of New England is not completely understood. Most workers recognize evidence for two glacial advances separated by an interglacial stage or substage (Schafer and Hartshorn, 1965). Others have suggested that all glacial stages are present in the region (Kaye, 1961, 1964). Glacial stages within the deposits offshore cannot be recognized in the seismic data. Older drifts and interglacial deposits may make up part of the sediments inferred to be coastal-plain deposits. More probably they may occur as part of the sediment labeled as moraine deposits, in a manner similar to that described by Kaye (1964) for the Pleistocene section on Martha's Vineyard. As such distinctions within the acoustic unit inferred to be moraine are not possible, the glacial history presented here describes events associated with the last glaciation of the area, which occurred in Woodfordian time.

Radiocarbon dates on material in the drift on outer Cape Cod (Zeigler and others, 1960; Oldale, 1968) suggest that the last ice advanced into southeastern New England 20,000 to 26,000 years ago. Fossil material, glauconite, and the paucity of feldspar in the drift (Oldale, 1968) also suggests that the ice overrode shelf sediments of Farmdalian Age as well as older glacial drift and coastal-plain sediments. The maximum advance of the ice was to Martha's Vineyard and Nantucket (Schafer and Hartshorn, 1965; Pratt and Schlee, 1969), where large terminal moraines were built by the Buzzards Bay, Cape Cod Bay, and possibly the South Channel lobes.

Retreat of the ice from this maximum position began sometime after $15,300 \pm 800$ B.P., as shown by a radiocarbon date (Kaye, 1964) on leaves found stratigraphically below till and outwash. Retreat of the lobes was not entirely synchronous. The Buzzards Bay lobe retreated somewhat faster than the Cape Cod Bay lobe (Schafer and Hartshorn, 1965), and the Cape Cod Bay lobe in turn retreated rather more rapidly than the South Channel lobe. The differential retreat of the lobes may have been caused by differences in the depth and size of the basins, the smallest of which is Buzzards Bay and by far the largest and deepest of which are Great South Channel and the basins to the north.

The first major stand in the retreat is marked by the outwash and moraines on inner Cape Cod that were deposited by the Buzzards Bay and Cape Cod Bay lobes. During this time, the extremities of the lobes were in positions approximated by the west and north shore of Cape Cod. The South Channel lobe occupied a more southerly position, so that 
its western edge was east of Nantucket. The possible formation of a lake between the ice lobes and the islands to the south is indicated by the thick clay layer in the subsurface of southeastern Cape Cod (Koteff and Cotton, 1962). The lake, if it existed, was probably dammed to the east by the South Channel lobe and to the south and west by drift. Progradation of outwash and deltaic sediments in a southerly direction appears to have filled the lake.

Retreat of the ice northward from Cape Cod resulted in a proglacial lake in Cape Cod Bay, dammed to the south and west by drift and to the east by the South Channel lobe. Initially the lake was narrow, and a minor stand of the ice resulted in deltaic and lacustrine deposits along the north shore of Cape Cod. Smaller moraines south of Plymouth (Schafer and Hartshorn, 1965) and a part of the drift on outer Cape Cod, deposited into the lake by melt water from the South Channel lobe, may correlate with this stand. Continued retreat of the ice from Cape Cod Bay to a position north of Duxbury allowed the lake to expand. Probably at this time, melt water from the South Channel lobe built most of the outer Cape, and to the west, melt water deposited sediments to form the deltas at Duxbury (Chute, 1965). Fine-grained sediments from the Cape Cod Bay and South Channel lobes were deposited in the lake, while the Cape Cod Bay lobe contributed coarse material to the lake sediments from ice or by rafting. As the western side of the South Channel lobe retreated away from the outer cape, the lake drained by way of Little Stellwagen Basin.

The glacial sediments of Cape Cod and in Cape Cod Bay were deposited sometime before 14,000 years ago, as by then the ice front had retreated to a position north of Boston (Kaye and Barghoorn, 1964) and the Cape Cod region was submerged. From the time when the drift was deposited on the outer cape, stages in the retreat of the South Channel lobe are not well known. However, the glacial deposits in Stellwagen Bank probably represent deltas formed in a marine environment. The finer grained glaciomarine sediments (rock flour) were deposited in Stellwagen Basin, possibly from melt water of the South Channel lobe, as the seismic recordings from the bank suggest an eastern source for these deposits. The glacial deposits atop Jeffreys Ledge and the fine-grained sediments in the basins west of the ledge probably have a similar origin. Continued shrinkage of the South Channel lobe resulted in the deposition of moraine sediments over the coastalplain sediments northeast of Stellwagen Bank and east of Jeffreys Ledge.

By about 12,000 years ago the western part of the Gulf of Maine was free of glacial ice. As the region was submerged, the glacial deposits atop the banks were reworked. The fines winnowed out of these deposits came to rest in the deeper and quieter water of the basins east and west of the topographic highs. The late Pleistocene high stand of sea level along much of coastal New England was due to the depression of the crust by ice loading. Sea level may have been as high as $37 \mathrm{~m}$ above the present level (Bloom, 1960; Kaye and Barghoorn, 1964). During this submergence a gray silt-clay that contains a cold-water marine fauna was deposited along the coast (pl. 1). In response to ice unloading, the crust rebounded and sea level dropped again. In Boston this emergence occurred 11,000 years ago when sea level dropped $21 \mathrm{~m}$ below its present level (Kaye and Barghoorn, 1964). Farther north in Maine the emergence occurred 4,200 years ago, and sea level dropped $2 \mathrm{~m}$ below its present level (Bloom, 1960). After this emergence, sea level rose again, reaching to nearly its present level several thousand years ago. During this last rise in sea level, deposition by littoral drift resulted in the formation of the northern tip of Cape Cod (Zeigler and others, 1965), as well as the barrier islands and spits along the New England coast, while modern streams have contributed silt and clay to the bathymetric lows.

\section{ECONOMIC DEPOSITS}

The relatively thin sediment cover indicated by the seismic profiles in the western Gulf of Maine, Nantucket and Vineyard Sounds, and Buzzards Bay demonstrates that the petroleum potential within the coastal-plain sediments appears to be nonexistent. The mineral resources of the region are probably restricted to sand and gravel. The geologic map compiled from the seismic profiles indicates that the best sites for these deposits are the top of banks and ledges. Smaller concentrations of sand and gravel are found locally along the coast and in Cape Cod Bay. In many places these smaller concentrations are covered by a variable thickness of marine mud of Holocene age. The large basins appear to contain little gravel, as in most places the transparent layer rests directly on basement. 


\section{REFERENCES}

Bloom, A. L., 1960, Late Pleistocene changes of sea level in southwestern Maine: Augusta, Me., Maine Geol. Survey, $143 \mathrm{p}$.

Bowman, Isaiah, 1906, Northward extension of the Atlantic preglacial deposits: Am. Jour. Sci., 4th ser., v. 22, p. 313-325.

Bradley, Edward, 1964, Geology and ground-water resources of southeastern New Hampshire: U.S. Geol. Survey Water-Supply Paper 1695, 78 p.

Chute, N. E., 1965, Geologic map of the Duxbury quadrangle, Plymouth County, Massachusetts: U.S. Geol. Survey Geol. Quad. Map GQ-466.

Chute, N. E., and Nichols, R. L., 1941, The geology of the coast of northeastern Massachusetts: Massachusetts Dept. Public Works Bull. 7, 48 p.

Cuppels, N. P., 1969, Surficial geologic map of the Georgetown quadrangle, Essex County, Massachusetts: U.S. Geol. Survey Geol. Quad. Map GQ-850.

Crosby, W. O., 1879, On the occurrence of fossiliferous boulders in the drift of Truro on Cape Cod, Massachusetts: Boston Soc. Nat. History Proc., v. 20, p. 136-140.

Drake, C. L., Worzel, J. L., and Beckmann, W. C., 1954, Geophysical investigations in the emerged and submerged Atlantic Coastal Plain. Part 9, Gulf of Maine: Geol. Soc. America Bull., v. 65, no. 10, p. 957-970.

Emerson, B. K., 1917, Geology of Massachusetts and Rhode Island: U.S. Geol. Survey Bull. 597, 289 p.

Flint, R. F., 1947, Glacial geology and the Pleistocene Epoch: New York, John Wiley \& Sons, 589 p.

Gibson, T. G., Hazel, J. E., and Mello, J. F., 1968, Fossiliferous rocks from submarine canyons off the northeastern United States: U.S. Geol. Survey Prof. Paper 600-D, p. D222-D230.

Goldthwait, J. W., Goldthwait, Lawrence, and Goldthwait, R. P., 1951, The geology of New Hampshire; Part I, Surficial geology: Concord, N.H., New Hampshire State Plan. and Devel. Comm., 83 p.

Holtedahl, Hans, 1958, Some remarks on geomorphology of continental shelves off Norway, Labrador, and southeast Alaska: Jour. Geology, v. 66, no. 4, p. 461-471.

Hoskins, Hartley, and Knott, S. T., 1961, Geophysical investigation of Cape Cod Bay, Massachusetts, using the continuous seismic profiler: Jour. Geology, v. 69, no. 3, p. $330-340$.

Johnson, D. W., 1925, The New England-Acadian shore line: New York, John Wiley \& Sons, 608 p.

Kaye, C. A., 1961, Pleistocene stratigraphy of Boston, Massachusetts: U.S. Geol. Survey Prof. Paper 424-B, p. B73-B76.

- 1964, Outline of Pleistocene geology of Martha's Vineyard, Massachusetts: U.S. Geol. Survey Prof. Paper 501-C, p. C134-C139.

Kaye, C. A., and Barghoorn, E. S., 1964, Late Quaternary sea-level change and crustal rise at Boston, Massachusetts, with notes on the autocompaction of peat: Geol. Soc. America Bull., v. 75, no. 2, p. 63-80.

King, L. H., MacLean, Brian, Bartlett, G. A., Teletzky, J. A., and Hopkins, W.S., Jr., 1970, Cretaceous strata on the Scotian Shelf: Canadian Jour. Earth Sci., v. 7, p. 145155.
Koteff, Carl, and Cotton, J. E., 1962, Preliminary results of recent deep drilling on Cape Cod, Massachusetts: Science, v. 137 , no. 3523, p. 34 .

LaForge, Laurence, 1932, Geology of the Boston area, Massachusetts: U.S. Geol. Survey Bull. 839, 105 p.

Oldale, R. N., 1968, Geologic map of the Wellfleet quadrangle, Barnstable County, Cape Cod, Massachusetts: U.S. Geol. Survey Geol. Quad. Map GQ-750.

- 1969, Seismic investigations on Cape Cod, Martha's Vineyard, and Nantucket, Massachusetts, and a topographic map of the basement surface from Cape Cod Bay to the Islands: U.S. Geol. Survey Prof. Paper $650-\mathrm{B}$, p. B122-B127.

Oldale, R. N., and Tuttle, C. R., 1964, Seismic investigations on Cape Cod, Massachusetts: U.S. Geol. Survey Prof. Paper 475-D, p. D118-D122.

1965, Seismic investigations in the Harwich and Dennis quadrangles, Cape Cod, Massachusetts: U.S. Geol. Survey Prof. Paper 525-D, p. D101-D105.

Oldale, R. N., and Uchupi, Elazar, 1970, The glaciated shelf off northeastern United States: U.S. Geol. Survey Prof. Paper 700-B, p. B167-B173.

Pratt, R. M., and Schlee, John, 1969, Glaciation on the continental margin off New England: Geol. Soc. America Bull., v. 80 , no. 11 , p. 2335-2341.

Sammel, E. A., Baker, J. A., and Brackley, R. A., 1966, Water resources of the Ipswich River basin, Massachusetts: U.S. Geol. Survey Water-Supply Paper 1826, 83 p.

Schafer, J. P., and Hartshorn, J. H., 1965, The Quaternary of New England, in Wright, H. E., Jr., and Frey, D. G., The Quaternary of the United States: Princeton, N.J., Princeton Univ. Press, p. 113-128.

Schlee, John, and Cheetham, A. H., 1967, Rocks of Eocene age on Fippennies Ledge, Gulf of Maine: Geol. Soc. America Bull., v. 78, no. 5, p. 681-684.

Shepard, F. P,. Trefethen, J. M., and Cohee, G. V., 1934, Origin of Georges Bank: Geol. Soc. America Bull., v. 45, no. 2, p. 281-302.

Smith, J. D., 1969, Geomorphology of a sand ridge: Jour. Geology, v. 77, no. 1, p. 39-55.

Stetson, H. C., 1949, The sediments and stratigraphy of the east coast continental margin-Georges Bank to Norfolk Canyon: Massachusetts Inst. Technology and Woods Hole Oceanog. Inst. Papers in Physical Oceanography and Meteorology, v. 11, no. 2, 60 p.

Tagg, A. R., and Uchupi, Elazar, 1966, Distribution and geologic structure of Triassic rocks in the Bay of Fundy and the northeastern part of the Gulf of Maine: U.S. Geol. Survey Prof. Paper 550-B, p. B95-B98.

Uchupi, Elazar, 1965, Map showing relation of land and submarine topography, Nova Scotia to Florida: U.S. Geol. Survey Misc. Geol. Inv. Map I-451, 3 sheets, scale: $1: 1,000,000$. 1966, Structural framework of the Gulf of Maine: Jour. Geophys. Research, v. 71, no. 12, p. 3013-3028.

1968, Atlantic Continental Shelf and Slope of the United States-Physiography: U.S. Geol. Survey Prof. Paper 529-C, 30 p.

Upson, J. E., and Spencer, C. W., 1964, Bedrock valleys of the New England coast as related to fluctuations of sea level: U.S. Geol. Survey Prof. Paper 454-M, 44 p.

U.S. Geological Survey, 1967, Engineering geology of the Northeast Corridor, Washington, D.C., to Boston, Massa- 
chusetts-Coastal Plain and surficial deposits: U.S.
Geol. Survey Misc. Geol. Inv. Map I-514-B, scale 1:250,000,8 sheets.

Woodworth, J. B., and Wigglesworth, Edward, 1934, Geography and geology of the region including Cape Code, the Elizabeth Islands, Nantucket, Marthas Vineyard, No Mans Land and Block Island: Harvard Coll. Mus. Comp. Zoology Mem., v. 52, 338 p.
Zeigler, J. M., Hoffmeister, W. S., Giese, Graham, and Tasha, Herman, 1960, Discovery of Eocene sediments in the subsurface of Cape Cod, Massachusetts: Science, v. 132, no. 3437 , p. $1397-1398$.

Zeigler, J. M., Tuttle, S. D., Tasha, H. J., and Giese, G. S., 1965, The age and development of the Provincelands Hook, outer Cape Cod, Massachusetts: Limnology and Oceanography, v. 10, supp., p. R298-R311. 

